\section{ISOLATION AND STRUCTURE OF A NEW $\varepsilon$-RHODOMYCIN COMPOUND PRODUCED BY A STREPTOMYCES SPECIES HPL Y-11472}

\author{
G. C. S. REDDY*, R. SAHAI ${ }^{\dagger}$,
} H. W. Fehlhaber ${ }^{\dagger \dagger}$ and B. N. GangulI

\author{
Microbiology Department, Research Centre, \\ Hoechst India Limited, \\ Mulund, Bombay 400 080, India \\ ${ }^{\dagger}$ Pharma Synthese, Hoechst AG., \\ Frankfurt, Federal Republic of Germany
}

(Received for publication April 11, 1985)

In screening for novel antitumor compounds a Streptomyces species HPL Y-11472 was isolated and found to produce a new $\varepsilon$-rhodomycin compound along with $\varepsilon$-rhodomycinone $e^{1,2,3)}$. This note describes the isolation and structure elucidation of this new compound.

Streptomyces species, HPL Y-11472, was fermented in 260 liters of medium containing (g per liter of $\mathrm{H}_{2} \mathrm{O}$ ) starch (10), glucose (10), malt extract (7.5), peptone (7.5), $\mathrm{NaCl}$ (3), $\mathrm{MgSO}_{4} \cdot 7 \mathrm{H}_{2} \mathrm{O}$ (1), $\mathrm{KH}_{2} \mathrm{PO}_{4}$ (2), $\mathrm{CuSO}_{4} \cdot 5 \mathrm{H}_{2} \mathrm{O}$ (0.007), $\mathrm{FeSO}_{4} \cdot 7 \mathrm{H}_{2} \mathrm{O}(0.001), \quad \mathrm{MnSO}_{4} \cdot 4 \mathrm{H}_{2} \mathrm{O}$ (0.008) and $\mathrm{ZnSO}_{4} \cdot 7 \mathrm{H}_{2} \mathrm{O}(0.002)$ in a 390 -liter fermenter at $26^{\circ} \mathrm{C}\left( \pm 1^{\circ} \mathrm{C}\right)$ for 72 hours. The culture filtrate (about 230 liters) and mycelium $(12 \mathrm{~kg})$ were extracted with EtOAc and acetone respectively and the concentrated extracts were combined and dissolved in toluene. The toluene layer was washed with $0.2 \mathrm{M}$ acetate buffer $(\mathrm{pH}$ 3.5 ) to remove basic components. One-tenth of the residue $(2.8 \mathrm{~g})$, obtained after removal of the toluene, was chromatographed on a silica gel column (eluted with $3 \% \mathrm{MeOH}$ in $\mathrm{CHCl}_{3}$ ) and further purified by the use of preparative TLC (developed with $\mathrm{CHCl}_{3}-\mathrm{MeOH}, 20: 1$ ). Two compounds 1 and 2 , were isolated as orange red crystals.

Compound 1, $\mathrm{mp} 220^{\circ} \mathrm{C}$ (dec) analyzed for $\mathrm{C}_{22} \mathrm{H}_{20} \mathrm{O}_{2}$ which was confirmed by mass spectroscopy $m / z 428\left(\mathrm{M}^{+}\right)$. Its spectral data are as follows: IR $\nu_{\max }^{\mathrm{KBr}} \mathrm{cm}^{-1} 3546,1730,1613,1460$, 1282; UV $\lambda_{\max }^{\mathrm{M} \text { MoH }} 212,234,254$ (sh), 296, 488, 510, 520,546 and 558 ; $\lambda_{\max }^{\mathrm{NaOH}-\mathrm{MeOH}} 580$ and $616 \mathrm{~nm}$; ${ }^{1} \mathrm{H}$ NMR $\delta_{\mathrm{TMS}}^{\mathrm{CDCl}} 1.15\left(3 \mathrm{H}, \mathrm{t}, J=8 \mathrm{~Hz}, \mathrm{CH}_{3}\right)$, $2.28\left(2 \mathrm{H}\right.$, br, $\left.\mathrm{CH}_{2}\right), 3.71\left(3 \mathrm{H}, \mathrm{s}, \mathrm{COOCH}_{3}\right)$,

$\uparrow$ Present address: The Waksman Institute of Microbiology, Rutgers, New Jersey, U.S.A.
$4.28(1 \mathrm{H}, \mathrm{s}, 10-\mathrm{H}), 5.35(1 \mathrm{H}, \mathrm{br}, 7-\mathrm{H}), 7.34(1 \mathrm{H}$, dd, $J=1.5$ and $8 \mathrm{~Hz}, 3-\mathrm{H}), 7.71(1 \mathrm{H}, \mathrm{t}, J=7 \mathrm{~Hz}$, $2-\mathrm{H}), 7.88(1 \mathrm{H}, \mathrm{dd}, J=1.5$ and $8 \mathrm{~Hz}, 1-\mathrm{H}), 12.11$, 12.92 and $13.45(3 \mathrm{H}, 3 \times \mathrm{s}, 3 \times \mathrm{OH}$ group $)$. The ${ }^{1} \mathrm{H}$ NMR spectrum showed the presence of three aromatic protons whose chemical shifts and coupling pattern revealed that they are located adjacent to each other. Apart from this, the ${ }^{1} \mathrm{H}$ NMR showed a carboxymethyl group at $\delta 3.71$ (the presence of a peak in the MS at $m / z 369$ which is $\mathrm{M}^{+}-\mathrm{COOCH}_{3}$, corroborates this statement), three hydrogen bonded phenolic $\mathrm{OH}$ groups and one primary methyl group at $\delta 1.15$. The presence of two nonphenolic $\mathrm{OH}$ groups was interpreted from the observation of MS fragmentation peaks at $\mathrm{m} / \mathrm{z}$ $410\left(\mathrm{M}^{+}-\mathrm{H}_{2} \mathrm{O}\right)$, and $\mathrm{m} / \mathrm{z} 392\left(\mathrm{M}^{+}-2 \mathrm{H}_{2} \mathrm{O}\right)$. In order to confirm the number and nature of the $\mathrm{OH}$ groups the compounds was acetylated with $\mathrm{Ac}_{2} \mathrm{O}$-pyridine at room temperature. The ${ }^{1} \mathrm{H}$ NMR of this acetylated derivative showed, apart from other signals, a singlet at $\delta 2.06$ characteristic of an acetyl group on an aliphatic hydroxyl and three singlets at $\delta 2.44$, 2.48 and 2.54 characteristic of phenolic acetyl groups. The $\mathrm{OH}$ group which did not acylate could be either a hindered or a tertiary one. The UV-visible spectrum of the compound is typical of anthracycline compounds. All these data are in agreement with those of $\varepsilon$-rhodomycinone $^{1,2,3)}$.

Compound 2: $\mathrm{mp} 130 \sim 135^{\circ} \mathrm{C}$; analyzed for $\mathrm{C}_{40} \mathrm{H}_{50} \mathrm{O}_{15}$. (Anal Calcd for $\mathrm{C}_{40} \mathrm{H}_{50} \mathrm{O}_{15}: \mathrm{C} 62.3$, H 6.5. Found: C 61.8, H 6.8); IR $\nu_{\max }^{\mathrm{CHCl}_{3}} \mathrm{~cm}^{-1}$<smiles>[R7]C1CC(O)(CC)C(C(C)=O)c2c(O)c3c(c(O)c21)C(=O)c1c(O)cccc1C3=O</smiles>

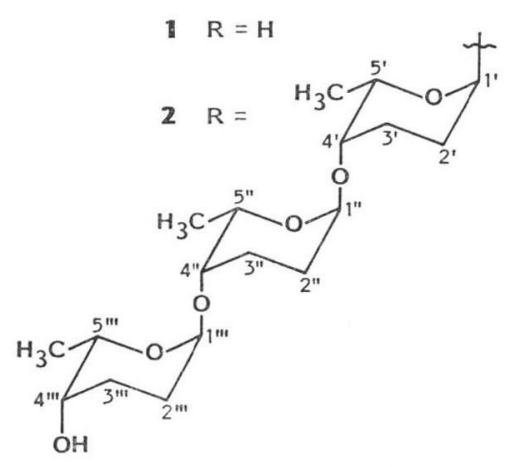


$3472,1710,1587,1567,1429,1277,1193,990$, 962; UV $\lambda_{\max }^{\mathrm{MeOH}} 235,253$ (sh), 294, 490, 510, 522, 544,$588 ; \lambda_{\max }^{\mathrm{NaOH}}-\mathrm{MeOH} 572$ and $612 \mathrm{~nm} ;{ }^{1} \mathrm{H}$ NMR $\delta_{\mathrm{TMI}}^{\mathrm{CDCl}} 1.1$ to $2.2\left(12 \mathrm{H}, \mathrm{m}, 4 \times \mathrm{CH}_{3}\right), 1.6(1 \mathrm{H}, \mathrm{br}$, $\mathrm{OH}), \quad 1.7$ to $2.25\left(14 \mathrm{H}, \mathrm{m}, 7 \times \mathrm{CH}_{2}\right), 2.36$ $\left(2 \mathrm{H}, \mathrm{m}, \mathrm{CH}_{2}\right), 3.51$ to $3.6\left(3 \mathrm{H}, \mathrm{m}, 4^{\prime}-, 4^{\prime \prime}-\right.$, $\left.4^{\prime \prime \prime}-\mathrm{H}\right), 3.7\left(3 \mathrm{H}, \mathrm{s}, \mathrm{COOCH}_{3}\right), 3.94$ to $4.12(3 \mathrm{H}$, m, 5'-, 5"'-, 5'"'-H), $4.3(1 \mathrm{H}, \mathrm{s}, 10-\mathrm{H}), 4.66(1 \mathrm{H}, \mathrm{s}$, $\mathrm{OH}), 4.83$ to $4.86\left(2 \mathrm{H}, \mathrm{m}, 1^{\prime \prime}-, 1^{\prime \prime \prime}-\mathrm{H}\right), 5.28(1 \mathrm{H}$, br, 7-H), $5.45\left(1 \mathrm{H}, \mathrm{br}, 1^{\prime}-\mathrm{H}\right), 7.34(1 \mathrm{H}, \mathrm{d}, J=$ $8 \mathrm{~Hz}, 3-\mathrm{H}), 7.7(1 \mathrm{H}, \mathrm{t}, J=8 \mathrm{~Hz}, 2-\mathrm{H}), 7.88(1 \mathrm{H}$, d, $J=8 \mathrm{~Hz}, 1-\mathrm{H}), 12.19,12.88$ and $13.52(3 \mathrm{H}$, $3 \times \mathrm{s}, 3 \times \mathrm{OH}$ group). These spectral data suggest that compound $\mathbf{2}$ is an anthracycline glycoside. On hydrolysis with $1 \mathrm{~N} \mathrm{HCl}$ at $110^{\circ} \mathrm{C}$ for 2 hours it yielded an aglycone which was identical with compound $\mathbf{1}$ in all respects (mp, TLC, IR and ${ }^{1} \mathrm{H}$ NMR). The hydrolysate after removal of the aglycone by extraction into $\mathrm{CHCl}_{3}$ was neutralized with Indion $\mathrm{HIP}\left(\mathrm{OH}^{-}\right)$ resin (anion exchange resin manufactured by Ion Exchange (India) Ltd.) and freeze dried. This sugar portion on TLC using silica gel plates $\left(60 \mathrm{~F}_{254}\right.$, E. Merck) in $\mathrm{BuOH}-\mathrm{AcOH}-\mathrm{H}_{2} \mathrm{O}$ (4:1:1) showed a single spot with $\mathrm{Rf}$ value 0.73 (visualization was carried out with $p$ anisaldehyde spray reagent) which agrees with that reported for a rhodinose sugar ${ }^{4}$ moiety. Further, the observation that compound $\mathbf{2}$ has more than one rhodinose unit was derived from both ${ }^{1} \mathrm{H}$ NMR data and partial hydrolysis experiments. Partial hydrolysis of compound 2 with $0.4 \mathrm{~N} \mathrm{HCl}$ at $40^{\circ} \mathrm{C}$ for 4 hours gave a compound with $\mathrm{Rf}$ of 0.4 (in $5 \% \mathrm{MeOH}$ in $\mathrm{CHCl}_{3}$ on silica gel plate) which was in between $\varepsilon$ rhodomycinone ( $\mathrm{Rf}$ 0.47) and compound 2 (Rf 0.35) along with free rhodinose sugar. This intermediate compound on further hydrolysis gave $\varepsilon$-rhodomycinone. Finally the ${ }^{1} \mathrm{H}$ NMR spectrum can be fully accounted for only on the basis of three rhodinose units. The attachment

Table 1. MIC of compound 2 .

\begin{tabular}{lc}
\hline \multicolumn{1}{c}{ Microorganism } & MIC $(\mu \mathrm{g} / \mathrm{ml})$ \\
\hline Staphylococcus aureus $209 \mathrm{P}$ & 125 \\
S. aureus 20240 & 125 \\
S. aureus $\mathrm{R} 85$ & 125 \\
S. aureus $\mathrm{R}$ 85/M & 125 \\
Bacillus subtilis & 63 \\
B. cereus ATCC 9634 & 63 \\
Enterococcus faecalis ATCC 8043 & 125 \\
Micrococcus luteus & $<2$ \\
Candida albicans & $>500$ \\
Escherichia coli 9632 & $>500$ \\
Proteus vulgaris & $>500$ \\
P. stuartii & $>500$ \\
Pseudomonas aeruginosa 20601 & $>500$ \\
Enterobacter cloacae & $>500$ \\
Klebsiella pneumoniae & $>500$ \\
Serratia marcescens & $>500$ \\
Paracolon Providencia & $>500$ \\
Citrobacter freundii & $>500$ \\
Alcaligenes faecalis & 250 \\
Salmonella typhimurium & $>500$ \\
\hline
\end{tabular}

Chart 1. FD mass spectral fragmentation pattern of compound 2.

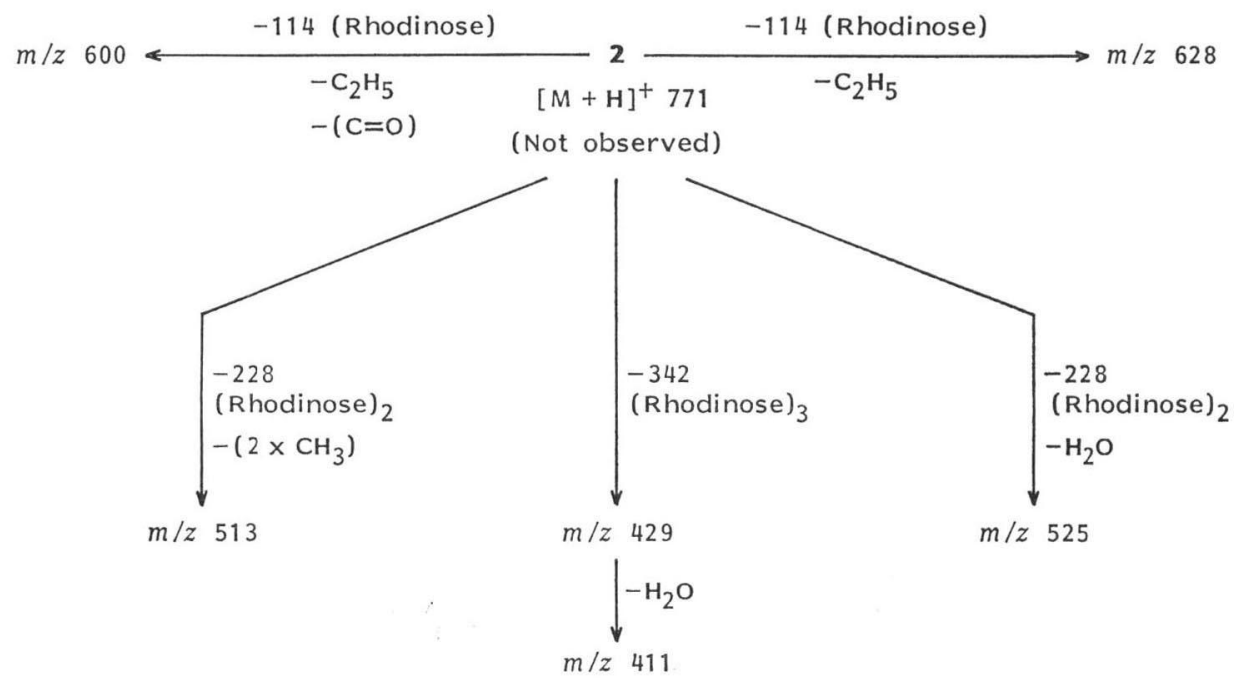


of the three rhodinose units to $\varepsilon$-rhodomycinone at $7-\mathrm{OH}$ and not at $9-\mathrm{OH}$ may be argued from the fact that the 9-OH is hindered and so far there are no reports in the literature of any anthracycline glycosides with the sugars attached at 9-OH. The field desorption mass spectrum of compound 2 did not give a $\mathrm{M}^{+}$peak, but the fragmentation pattern depicted in Chart 1 offers additional evidence for the structure to be $\varepsilon$ rhodomycinone-7-(rhodinose) $)_{3}$. The minimum inhibitory concentrations (MIC) of compound 2 against various microorganisms are given in Table 1.

\section{Acknowledgments}

We thank Mr. H. B. Chaubal for his technical assistance and Mr. K. R. DesiKAN for excellent fermentation support.

\section{References}

1) Brockmann, H. \& B. Franck: Rhodomycinone and isorhodomycinone, rhodomycine. IV. Antibiotics from Actinomycetes. XXXIII. Chem. Ber. 88: 1792 1818, 1955

2) Brockmann, H. \& H. Brockmann, Jr.: Rhodomycine. VI. Antibiotics from Actinomycetes. XLVII. Chem. Ber. 94: 2681 2694, 1961

3) BowIE, J. H. \& A. W. Johnson: $\theta$-Rhodomycinone. J. Chem. Soc. 1964: 3927 3931, 1964

4) OKI, T.; I. Kitamura, Y. Matsuzawa, N. Shibamoto, T. Ogasawara, A. Yoshimoto, T. InUi, H. Naganawa, T. TakeUchi \& H. UmeZAWA: Antitumor anthracycline antibiotics, aclacinomycin A and analogues. II. Structural determination. J. Antibiotics 32: 801 819, 1979 